\title{
Studi Komparasi Sekolah Menengah Kejuruan yang Efektif di Daerah Istimewa Yogyakarta
}

\section{Dr. Irwanto, MT. \\ Abstrak}

Tujuan penelitian ini adalah untuk mengungkapkan secara mendalam dan komprehensif tentang SMK yang efektif mengenai aspek (1) kurikulum, (2) PBM, (3) pendidik dan tenaga kependidikan, (4) penilaian pendidikan dan (5) kultur sekolah di SMKN di Yogyakarta. Dengan penelitian ini diharapkan diperoleh data dan solusi yang tepat untuk peningkatan mutu dan kualitas lulusan SMK yang bisa memberikan konstribusi besar terhadap pendidikan di Indonesia.

Metode penelitian ini merupakan penelitian studi multi kasus yang dilaksanakan di DIY yang berlokasi di SMKN 2 Yogyakarta, SMKN 2 Depok dan SMKN 2 Wonosari. Sumber informasi meliputi kepala sekolah, guru, karyawan dan siswa. Data dikumpulkan melalui observasi langsung, wawancara secara mendalam dan dokumentasi. Instrumen utama yang digunakan dalam penelitian ini adalah peneliti sendiri. Keabsahan data dilakukan dengan cara triangulasi. Teknik analisis data yang digunakan dalam penelitian ini adalah dengan cara reduksi data, penyajian data dan penarikan kesimpulan/verifikasi teknik ini juga disebut sebagai teknik interaktif yang dikembangkan oleh Miles dan Huberman (1994).

Hasil penelitian dari ketiga SMKN di DIY menunjukkan bahwa SMK tersebut sudah termasuk SMKN yang efektif di DIY yang mencakup lima aspek sebagai berikut. (1) Kurikulum yang digunakan di SMKN 2 Yogyakarta, SMKN 2 Depok dan SMKN 2 Wonosari adalah kurikulum KTSP secara utuh dan benar serta ada pengembangan kurikulumnya. Pengembangan kurikulum merupakan masukan dari DUDI untuk pihak SMK agar terjadi link and match antara kurikulum SMK dengan kebutuhan yang dibutuhkan oleh DUDI. Dengan harapan adanya pengembangan kurikulum agar lulusan SMK dapat menguasai kompetensi dasar yang di butuhkan oleh DUDI. Pihak sekolah sudah menjalin kerjasama dengan DUDI untuk menyusun kompetensi yang dibutuhkan DUDI serta pihak SMK mempersiapkan lulusan yang dibutuhkan oleh DUDI. Kurikulum yang diberlakukan sudah menggunakan standar isi KTSP, silabus, RPP, bahan ajar, media pembelajaran dan strategi atau metode pembelajaran yang dilaksanakan oleh pihak sekolah. (2) Ketiga SMK menekankan pembelajaran aktif, kreatif dan menyenangkan (PAKEM) serta penggunaan media pembelajaran, strategi pembelajaran yang bervariasi. Pengelolaan kelas, bengkel dan laboratorium sudah efektif karena adanya interaksi antara guru dan siswa dalam PBM. Strategi pembelajaran yang biasanya digunakan ketiga SMKN yaitu strategi kooperatif, kontektual, studi kasus, diskusi, realistik (realistic mathematics education) dan pembelajaran berbasis masalah. (3) Pendidik dan tenaga kependidikan di SMKN 2 Yogyakarta, SMKN 2 Depok dan SMKN 2 Wonosari sudah efektif karena memenuhi standar kompetensi seorang guru diantaranya kompetensi kepribadian, kompetensi pedagogik, kompetensi profesional dan kompetensi sosial serta kualifikasi seorang guru yang akan mengajar di sekolah tersebut. Dari ketiga SMKN di DIY semua guru yang mengajar sudah sesuai dengan bidang keilmuannya masing-masing. Pendidik dan tenaga kependidikan dari ketiga SMKN di DIY 
sudah dapat dikatakan efektif karena $80 \%$ sudah berkualifikasi S1, 25\% sudah berkualifikasi S2 dan S3, 3\% berkualifikasi D3 dan 2\% berkualifikasi SMA/SMK. (4) Penilaian pendidikan dari ketiga SMKN di DIY sudah efektif karena semua sudah melaksanakan sesuai dengan standar penilaian pendidikan yang ditentukan bersama dengan warga sekolah. Penilaian sudah mengacu kepada penilaian standar pada KTSP, PAP dan penilaian kriteria. (5) Kultur ketiga SMKN sudah efektif dalam pelaksanaan PBM teori maupun praktik di sekolah. Kultur kerja seperti di DUDI sudah dilaksanakan di SMKN 2 Yogyakarta, SMKN 2 Depok dan SMKN 2 Wonosari, dimana masing-masing SMK sudah mendapatkan proyek dari luar sekolah yang dikerjakan oleh pihak SMK terutama para guru dan dibantu oleh siswa dalam rangka menyelesaikan proyek tersebut. Dengan adanya kultur kerja DUDI di SMK yang positif maka akan menghasilkan PBM teori dan praktik yang efektif serta lulusan yang bermutu dan berkualitas serta siap pakai di DUDI .

Kata Kunci: Sekolah Menengah Kejuruan Efektif

\section{Pendahuluan}

Undang-undang Sistem Pendidikan Nasional (UUSPN) No. 20 Pasal 3 dan Penjelasan Pasal 15 tahun 2003 menyebutkan bahwa Sekolah Menengah Kejuruan (SMK) merupakan pendidikan menengah yang mempersiapkan peserta didik terutama bekerja dalam bidang tertentu. SMK merupakan pendidikan menengah dan jalur pendidikan formal dari sistem pendidikan di Indonesia. Sebagai lembaga pendidikan menengah dan lembaga pendidikan formal, SMK mempunyai tujuan mempersiapkan siswa untuk memasuki lapangan kerja serta mengembangkan sikap profesional dan menyiapkan tenaga kerja tingkat menengah untuk mengisi kebutuhan Dunia Usaha dan Dunia Industri (DUDI) pada saat ini maupun masa yang akan datang.

Alasan untuk mengambil tempat penelitian di SMKN 2 Yogyakarta, SMKN 2 Depok dan SMKN 2 Wonosari karena ketiga sekolah tersebut memiliki animo yang tinggi dari masyaraakat serta beberapa indikator yang digunakan oleh peneliti sudah memenuhi persyaratan untuk bisa dikomparasikan dari ketiga sekolah tersebut. Untuk status sekolah yang diambil hanya SMK negeri pada kelompok teknologi dan industri yang berada di DIY yang memiliki beberapa keunggulan dari SMKN yang lain. SMKN 2 Yogyakarta, SMKN 2 Depok dan SMKN 2 Wonosari merupakan SMK yang terpilih di dalam penelitian ini untuk mengetahui secara mendalam dan komprehensif mengenai ketiga SMK tersebut.

Indikator yang digunakan dalam memilih SMKN pada kelompok teknologi dan industri yang dijadikan sebagai sampel di dalam penelitian yang berjudul studi komparasi SMK yang efektif di DIY yaitu (1) profil sekolah, (2) nilai rata-rata Ujian Akhir Nasional (UAN), (3) sertifikat ISO, (4) jumlah tenaga pendidik yang sudah bersertifikat pendidik, (5) tingkat kelulusan sekolah, (6) kerjasama sekolah dengan DUDI, (7) masa tunggu kerja setelah lulus dari sekolah, (8) akreditasi sekolah, (9) kategori sekolah, (10) kelompok keahlian sekolah, (11) status 
sekolah dan (12) kejuaraan Lomba Kompetensi Siswa (LKS).

Berdasarkan latar belakang masalah, identifikasi dan pembatasan masalah di atas, maka rumusan masalah penelitian ini difokuskan pada: (1) Bagaimana gambaran karakteristik kurikulum yang efektif di SMK DIY? (2) Bagaimana gambaran karakteristik PBM yang efektif di SMK DIY? (3) Bagaimana gambaran karakteristik pendidik dan tenaga kependidikan yang efektif di SMK DIY? (4) Bagaimana gambaran karakteristik penilaian pendidikan yang efektif di SMK DIY? (5) Bagaimana karakteristik kultur sekolah yang efektif di SMK DIY?.

\section{Kajian Pustaka}

\section{A. Pendidikan Kejuruan}

Walter (1993: 5) mengatakan bahwa penyelenggaraan pendidikan kejuruan harus difokuskan dan diarahkan pada program-program pendidikan yang mengarah pada kesiapan individu dalam rangka mempersiapkan dirinya sebagai pekerja, baik dibayar ataupun tidak dibayar. Finch dan Crunkilton (1979: 111) menjelaskan bahwa pendidikan kejuruan menekankan pada pengembangan keterampilan, pengembangan kemampuan unjuk kerja dan penyiapan untuk mendapatkan pekerjaan. Pendidikan kejuruan tidak hanya terkait dengan pengembangan keterampilan, tapi juga pengembangan seluruh kompetensi yang dimiliki peserta didik untuk mengekspresikan dirinya dalam bekerja. Seluruh kompetensi yang dapat dikembangkan Wenrich dan Wenrich (1974: 38) melibatkan semua domain yang terdapat pada peserta didik yaitu pengetahuan, keterampilan dan sikap kerja sedangkan potensi peserta didik mencakup perasaan, penglihatan, pikiran dan tindakan. Berdasarkan pengertian tentang pendidikan kejuruan di atas dapat dikatakan bahwa pendidikan kejuruan identik dengan pendidikan pekerjaan yang berkaitan langsung dengan cara memberdayakan seluruh potensi peserta didik agar ia dapat memiliki suatu kompetensi tertentu sehingga kelak mampu memasuki dunia kerja. Pendapat lain yang lebih spesifik adalah yang dikemukakan oleh Perkins (1998: 101392) yaitu:

Vocational education as organized educational programs offering a sequence of courses directly related to preparing individuals for paid or unpaid employment in current. Programs include competency-based applied learning, which contributes to an individual's academic knowledge, higher-order reasoning, problem solving skills, and the occupationalspecific skills necessary for economic independence as a productive and contributing member of society.

Prinsip-prinsip yang harus dipegang dalam penyelenggaraan pendidikan kejuruan dijelaskan Miller (1986) sebagai berikut: (1) Guidance is essensial component of vocational education, (2) Life long learning is promoted through vocational education, (3) Needs of the community are reflekted by programs of vocationa education, (4) Vocational education is open to all, (5) Placement in the nextstep is responsibility of vocational education, (6) Eliminations of sex bias and sex role stereotyping is promoted through vocational educatio, (7) Individual with 
special needs are served through vocational education, (8) Student organization are an integral feature of vocational education, (9) Eachers of vocational education are both profesionally and occupationally component and (10) A possitive work ethic is promoted through vocational education.

\section{B. Komponen-komponen Sekolah Menengah Kejuruan yang Efektif 1. Kurikulum}

Kurikulum merupakan seperangkat rencana dan pengaturan mengenai isi dan bahan pelajaran serta cara yang digunakan sebagai pedoman penyelenggaraan kegiatan pembelajaran untuk mencapai kompetensi tertentu. Kurikulum dapat pula didefinisikan apa yang harus diajarkan kepada peserta didik agar yang bersangkutan menguasai kompetensi/kemampuan yang telah ditetapkan dan diekspresikan dalam bentuk tujuan pembelajaran yang akan dicapai (Slamet, 2005: 318).

\section{Proses Belajar Mengajar}

PBM adalah serangkaian aktivitas yang terdiri dari persiapan, pelaksanaan, dan evaluasi pembelajaran. Ketiga hal tersebut merupakan rangkaian utuh yang tidak dapat dipisah-pisahkan. Persiapan PBM adalah penyiapan satuan acara pelajaran (SAP) yang meliputi, antara lain, tujuan instruksional, alat evaluasi, bahan ajar, metode pembelajaran, media/alat peraga pendidikan, fasilitas, waktu, tempat, dana, harapan-harapan, dan perangkat informasi yang diperlukan untuk mendukung pelaksanaan PBM. Kesiapan siswa, baik fisik maupun mental, juga merupakan hal penting. Jadi, esensi persiapan PBM adalah kesiapan segala hal yang diperlukan untuk berlangsungnya pelaksanaan PBM.

\section{Pendidik dan Tenaga Kependidikan}

Pendidik dan tenaga kependidikan adalah mereka yang berkualifikasi sebagai pendidik, pengelola dan tenaga penunjang pendidikan. Pendidik bertugas merencanakan, melaksanakan dan menilai serta mengembangkan proses pembelajaran. Pengelola sekolah bertugas mengelola dan memimpin tenaga pendidik dan tenaga penunjang di sekolah. Tenaga penunjang sekolah adalah mereka yang bertugas mendukung penyelenggaraan proses pembelajaran di sekolah.

\section{Penilaian Pendidikan}

Penilaian pendidikan adalah hasil belajar yang merefleksikan seberapa baik peserta didik mampu mengikuti proses pembelajaran. Idealnya, hasil belajar harus mengekspresikan tiga unsur kemampuan, yaitu daya pikir, daya kalbu, dan daya fisik. Pertama, kemampuan daya pikir tidaklah semata-mata mengukur prestasi belajar berupa NEM saja, akan tetapi harus juga mengukur kemampuan berpikir ganda, seperti misalnya berpikir deduktif, induktif, ilmiah, kritis, kreatif, nalar, eksploitatif, diskoveri, lateral, dan berpikir sistem. Kedua, hasil belajar harus juga mengukur kemampuan daya kalbu, yang pada dasarnya adalah mengukur kualitas batiniyah/karakter manusia, seperti misalnya iman dan taqwa terhadap Tuhan Yang Maha Esa, kasih sayang, kejujuran, kesopanan, toleransi, tanggungjawab, keberanian moral, komitmen, disiplin diri, dan estetika. Ketiga, hasil belajar harus juga mengukur daya fisik, yang meliputi keterampilan olahraga (atletik, sepak bola, badminton, dan sebagainya), kesehatan 
(daya tahan, bebas penyakit), dan kesenian (musik, visual, teater dan kriya). Oleh karena itu, tidaklah cukup jika hasil belajar hanya diukur dengan hasil tes berupa NEM.

\section{Kultur Sekolah}

Kultur sekolah adalah karakter atau pandangan hidup (a way of life) sekolah yang merefleksikan keyakinan, nilai, norma, simbol dan tradisi/kebiasaan yang telah dibentuk dan disepakati bersama oleh warga sekolah. Definisi ini mengingatkan pada kita bahwa kultur sekolah merupakan peleburan unsur-unsur aset kualitas batiniyah (akal, emosi, rasa, spirit) yang kemudian diekspresikan dalam bentuk sikap dan perbuatan lahiriyah. Hasil-hasil penelitian menyimpulkan bahwa kultur sekolah sangat berpengaruh terhadap efektivitas sekolah. Artinya, makin kondusif kultur sekolah, makin efektif sekolahnya.

\section{Hakikat Sekolah Efektif}

Scheerens (1992: 3) menyatakan bahwa suatu sekolah disebut 'efektif' apabila terdapat kesamaan atau kesesuaian antara tujuan dan pencapaiannya. Namun demikian, keefektifan bukan merupakan suatu kondisi yang sifatnya dikhotomis. Dalam arti, suatu sekolah mungkin hanya "efektif sebagian", yang berarti bahwa sekolah tersebut hanya efektif dalam mencapai tujuan pada bidang tertentu saja (aspek tertentu), tetapi kurang efektif dalam mencapai target-target pada bidarg yang lain. Sebagai misalnya suatu sekolah yang efektif dalam pengembangan prestasi akademik (yang diukur dari hasil belajar siswa), mungkin kurang efektif dalam pencapaian tujuan dalam aspek sosial (yang diukur dari perasaan memiliki dan rasa suka siswa terhadap sekolah). Di samping itu, aspek lain yang perlu dipertimbangkan dalam mendefinisikan sekolah efektif adahh bahwa sekolah tidak sama keefektifannya pada semua kelompok siswa. Banyak hasil penehtian menunjukkan bahwa suatu sekolah seringkali hanya efektif untuk kelompok siswa tertentu misalnya lebih efektif untuk siswa laki-laki dan kurang efektif untuk siswa perempuan, efektif untuk kelompok etnis tertentu atau untuk siswa dengan kemampuan akademik tertentu.

Segiovanni (1995: 2) mengemukakan bahwa karakteristik sekolah efektif yaitu (1) terpusat pada siswa, (2) kaya akan berbagai program akademik, (3) menyediakan pembelajaran yang mendorong siswa belajar, (4) memiliki iklim sekolah yang positif, (5) membantu interaksi siswa, (6) pengembangan staf secara ekstensif, (7) kepemimpinan yang praktis, (8) kreatif membantu pemecahan masalahdan (9) memiliki hubungan kuat dengan masyarakat dan orangtua tua siswa.

\section{Sekolah Menengah Kejuruan Efektif}

Pembelajaran yang sering juga disebut dengan belajar mengajar sebagai terjemahan dari istilah "instruction" terdiri dari dua kata, belajar dan mengajar (teaching and learning). Belajar adalah suatu proses yang di tandai dengan adanya perubahan pada diri seseorang. Hal ini sesuai dengan pendapat Ormrod (2003: 188) menyatakan bahwa "learning is a relatively permanent change in behavior due to experience". Belajar adalah perubahan perilaku yang relatif permanen sebagai akibat pengalaman. Pengalaman dalam kegiatan belajar dapat merupakan 
sesuatu yang dialami sendiri maupun pengalaman orang lain.

\section{Metode Penelitian}

\section{A. Jenis Penelitian}

Berdasarkan fokus dalam penelitian ini, penelitian ini dikategorikan pada penelitian studi multi kasus karena tempat penelitian lebih dari satu SMK yang diteliti sehingga bisa menemukan SMK yang efektif di DIY. Penelitian ini mengunakan pendekatan kualitatif dengan jenis penelitian multi studi kasus. Menurut Robert Stake (Denzin dan Lincoln, 2009: 299) multi studi kasus bukanlah sebuah pilihan metodologis, namun lebih sebagai pilihan objek yang diteliti.

\section{B. Tempat dan Waktu Penelitian 1. Tempat Penelitian}

Sesuai dengan fokus penelitian, lokasi penelitian yang akan dijadikan sebagai tempat penelitian di SMKN DIY yaitu SMKN 2 Yogyakarta, SMKN 2 Depok Sleman, dan SMKN 2 Wonosari Gunungkidul.

\section{Waktu Penelitian}

Penelitian ini akan dilaksanakan di SMKN di DIY, dengan mengambil lokasi pada tiga SMKN yaitu SMKN 2 Yogyakarta, SMKN 2 Depok dan SMKN 2 Wonosari. Penelitian ini direncanakan berlangsung selama lima bulan untuk pengambilan data yaitu bulan Agustus sampai dengan Desember 2014.

\section{Subjek dan Objek Penelitian \\ 1. Subjek Penelitian}

Subjek penelitian yaitu warga sekolah di SMKN 2 Yogyakarta, SMKN 2 Depok dan SMKN 2 Wonosari yang bertanggungjawab dan terlibat secara langsung dalam aspek kurikulum, PBM, pendidik dan tenaga kependidikan, penilaian pendidikan dan kultur sekolah yaitu kepala sekolah, wakasek urusan kurikulum,

guru, karyawan dan siswa serta pihak yang diperlukan dan berhubungan dengan penelitian ini.

\section{Objek Penelitian}

Objek penelitian ini adalah kurikulum, PBM, pendidik dan tenaga kependidikan serta kultur sekolah yang dilakukan SMKN 2 Yogyakarta, SMKN 2 Depok Sleman dan SMKN 2 Wonosari Gunungkidul Propinsi DIY.

\section{Instrumen Penelitian}

Dalam penelitian ini, instrumen utama adalah peneliti sendiri, selanjutnya untuk mempertajam dan melengkapi data penelitian digunakan lembar pengamatan, panduan wawancara dan catatan lapangan

\section{E. Teknik Pengumpulan Data}

Dalam penelitian ini peneliti mengumpulkan data menggunakan teknik observasi, wawancara dan dokumentasi yang diuraikan sebagai berikut:

\section{Observasi}

Observasi dilakukan dengan cara ikut ambil bagian atau melibatkan diri dalam situasi dan kegiatan subjek penelitian.

\section{Wawancara}


Wawancara dilakukan dengan cara menanyakan serentetan pertanyaan yang sudah terstruktur, kemudian dikembangkan satu persatu untuk memperoleh keterangan yang mendalam.

\section{Dokumentasi}

Metode dokumentasi ini digunakan untuk memperoleh informasi mengenai (1) profil SMKN 2 Depok, SMKN 2 Yogyakarta dan SMKN 2 Wonosari yang meliputi sejarah sekolah, letak geografis, visi dan misi dan struktur organisasi, (2) data tentang pendidik dan tenaga kependidikan (jumlah, kualifikasi pendidikan, bidang studi dan tugas), (3) data tentang peserta didik/siswa (jumlah dan jenis kelamin dan nilai UAN), (4) keadaan sarana dan prasarana, (5) peraturan/tata tertib sekolah dan (6) prestasi siswa. Selain itu, peneliti melakukan dokumentasi sendiri terhadap beberapa objek yang dianggap perlu dengan mengambil gambar/foto seperti foto kondisi fisik sekolah.

\section{G. Teknik Analisis Data}

Dalam penelitian ini, analisis data sudah dilakukan sejak awal kegiatan penelitian sampai akhir penelitian. Dengan cara ini diharapkan terdapat konsistensi analisis data secara keseluruhan. Untuk menyajikan data tersebut agar lebih bermakna dan mudah dipahami, maka langkah analisis data yang digunakan dalam penelitian ini adalah Analysis Interactive Model dari Miles dan Huberman (1994: 21) yang membagi kegiatan analisis menjadi beberapa bagian yaitu: pengumpulan data, pengelompokan menurut komponen, reduksi data, penyajian data, memisahkan outlier data dan penarikan kesimpulan atau verifikasi data. Dari keempat komponen tersebut merupakan bagian yang saling terkait satu sama lain dan kegiatan analisis data dengan model interaktif tersebut atau analisis alur dapat dilihat pada Gambar 1 di bawah ini.

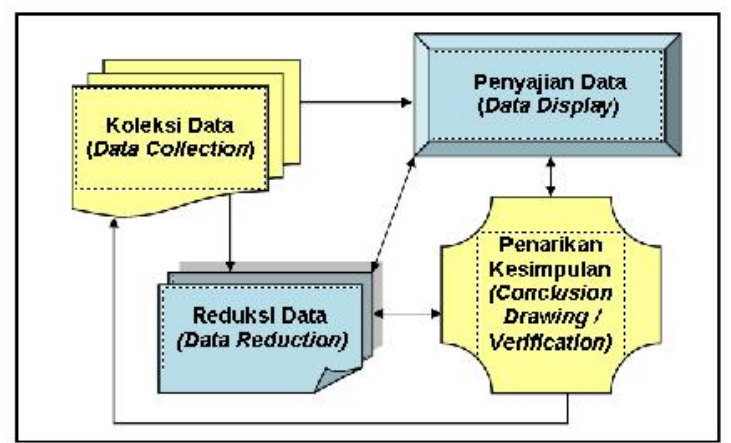

Gambar 1.

$$
\begin{gathered}
\text { Alur analisis data kualitatif } \\
\text { berdasarkanmodel interaktif Miles dan } \\
\text { Huberman, 1994: 23) }
\end{gathered}
$$

\section{Hasil Penelitian}

Hasil penelitian menunjukkan bahwa SMKN yang efektif di DIY disajikan dalam bentuk komparasi dari ketiga SMKN di DIY tersebut. Ketiga SMKN di DIY tersebut dilihat secara mendalam dan komprehensif mengenai kurikulum, PBM, pendidik dan tenaga kependidikan, penilaian pendidikan dan kultur sekolah di SMKN 2 Yogyakarta, SMKN 2 Depok dan SMKN 2 Wonosari. Tabel 6 di bawah ini merupakan hasil rekapan makna pada masing-masing komponen kurikulum, PBM, pendidik dan tenaga kependidikan, penilaian pendidikan dan kultur sekolah di SMKN 2 Yogyakarta, SMKN 2 Depok dan SMKN 2 Wonosari. 
Tabel 1. Hasil komparasi SMKN yang efektif di DIY

\begin{tabular}{|c|c|c|c|c|}
\hline No & $\begin{array}{c}\text { Kompone } \\
\text { n }\end{array}$ & SMKN 2 Yogyakarta & SMKN 2 Depok & SMKN 2 Wonosari \\
\hline 1 & $\begin{array}{l}\text { Kurikulu } \\
\text { m }\end{array}$ & $\begin{array}{l}\text { 1. Menggunakan } \\
\text { kurikulum KTSP } \\
\text { secara utuh dan } \\
\text { benar. } \\
\text { 2. Adanya } \\
\text { pengembangan } \\
\text { kurikulum dari } \\
\text { DUDI. } \\
\text { 3. Kurikulum yang luas } \\
\text { dan berimbang. } \\
\text { 4. Kerjasama dengan } \\
\text { DUDI. } \\
\text { 5. Pembuatan silabus, } \\
\text { RPP serta materi } \\
\text { pembelajaran baik } \\
\text { teori maupun } \\
\text { praktik. } \\
\text { 6. Kurikulum } \\
\text { dikembangkan } \\
\text { secara sistematis dan } \\
\text { berkesinambungan } \\
\text { sejalan dengan } \\
\text { perubahan tujuan } \\
\text { yang akan dicapai. } \\
\text { 7. Kurikulum disusun } \\
\text { berdasarkan } \\
\text { kemajuan IPTEK } \\
\text { mutakhir dan } \\
\text { canggih. } \\
\text { 8. Memiliki tim } \\
\text { pengembangan } \\
\text { kurikulum setiap } \\
\text { mata pelajaran. }\end{array}$ & $\begin{array}{l}\text { 1. Menggunakan kurikulum } \\
\text { KTSP secara utuh dan } \\
\text { benar. } \\
\text { 2. Adanya kerjasama antara } \\
\text { industri dengan sekolah . } \\
\text { 3. Memberikan } \\
\text { pembelajaran aktif dan } \\
\text { efektif. } \\
\text { 4. Program pembelajaran } \\
\text { mencakup akademik, } \\
\text { sosial, religi, kepribadian, } \\
\text { mulok dan fisik siswa. } \\
\text { 5. Mendorong siswa } \\
\text { mempunyai sikap positif } \\
\text { terhadap belajar. } \\
\text { 6. Pembuatan silabus, RPP } \\
\text { serta materi pembelajaran } \\
\text { baik teori maupun } \\
\text { praktik. } \\
\text { 7. Kurikulum } \\
\text { dikembangkan secara } \\
\text { sistematis dan } \\
\text { berkesinambungan } \\
\text { sejalan dengan perubahan } \\
\text { tujuan yang akan dicapai. } \\
\text { 8. Kurikulum disusun } \\
\text { berdasarkan kemajuan } \\
\text { IPTEK mutakhir dan } \\
\text { canggih. } \\
\text { 9. Adanya tim } \\
\text { pengembangan } \\
\text { kurikulum yang anggota- } \\
\text { anggotanya } \\
\text { merefleksikan kelompok- } \\
\text { kelompok keahlian yang } \\
\text { terkait dengan setiap } \\
\text { mata pelajaran. } \\
\text {. }\end{array}$ & $\begin{array}{l}\text { 1. Menggunakan kurikulum } \\
\text { KTSP secara utuh dan } \\
\text { benar. } \\
\text { 2. Adanya pengembangan } \\
\text { kurikulum yang dilakukan } \\
\text { melalui kurikulum- } \\
\text { kurikulum yang terdahulu. } \\
\text { 3. Kerjasama dengan industri. } \\
\text { 4. Kurikulum yang luas dan } \\
\text { berimbang. } \\
\text { 5. Pembuatan silabus, RPP } \\
\text { serta materi pembelajaran } \\
\text { baik teori maupun praktik. } \\
\text { 6. Adanya hubungan atau } \\
\text { keterkaitan langsung dan } \\
\text { jelas antara tujuan yang } \\
\text { akan dicapai. } \\
\text { 7. Kurikulum dikembangkan } \\
\text { secara sistematis dan } \\
\text { berkesinambungan sejalan } \\
\text { dengan perubahan tujuan } \\
\text { yang akan dicapai. } \\
\text { 8. Kurikulum disusun } \\
\text { berdasarkan kemajuan } \\
\text { IPTEK mutakhir dan } \\
\text { canggih. } \\
\text { 9. Tim pengembangan } \\
\text { kurikulum yang anggota- } \\
\text { anggotanya merefleksikan } \\
\text { kelompok-kelompok } \\
\text { keahlian yang terkait } \\
\text { dengan setiap mata } \\
\text { pelajaran. }\end{array}$ \\
\hline 2 & $\begin{array}{l}\text { Proses } \\
\text { belajar } \\
\text { mengajar }\end{array}$ & $\begin{array}{l}\text { 1. Menumbuhkan dan } \\
\text { mengembangkan } \\
\text { daya kreasi, inovasi, } \\
\text { nalar dan eksperimen } \\
\text { untuk menemukan } \\
\text { kemungkinan- } \\
\text { kemungkinan baru, } a\end{array}$ & $\begin{array}{l}\text { 1. Mengembangkan daya } \\
\text { kreasi, inovasi, nalar dan } \\
\text { eksperimen untuk } \\
\text { menemukan } \\
\text { kemungkinan- } \\
\text { kemungkinan baru, a joy } \\
\text { of discovery. }\end{array}$ & $\begin{array}{l}\text { 1. Menumbuhkan dan } \\
\text { mengembangkan daya } \\
\text { kreasi, inovasi, nalar dan } \\
\text { eksperimen untuk } \\
\text { menemukan } \\
\text { kemungkinan- } \\
\text { kemungkinan baru, a joy }\end{array}$ \\
\hline
\end{tabular}




\begin{tabular}{|c|c|c|c|c|}
\hline No & $\begin{array}{c}\text { Kompone } \\
\text { n }\end{array}$ & SMKN 2 Yogyakarta & SMKN 2 Depok & SMKN 2 Wonosari \\
\hline & & $\begin{array}{l}\text { joy of discovery. } \\
\text { 2. Menekankan } \\
\text { pembelajaran aktif, } \\
\text { kreatif dan } \\
\text { menyenangkan } \\
\text { (PAKEM), student } \\
\text { centered, reflective } \\
\text { learning, active } \\
\text { learning, enjoyble } \\
\text { and joyful learning, } \\
\text { cooperative learning, } \\
\text { quantum learning, } \\
\text { learning revolution } \\
\text { and contextual } \\
\text { learning. } \\
\text { 3. Lingkungan belajar } \\
\text { yang kondusif. } \\
\text { 4. Media dan strategi } \\
\text { dalam pembelajaran. } \\
\text { 5. Pembelajaran teori } \\
\text { daan praktik } \\
\text { dilaaksanakan secara } \\
\text { menyatuh. } \\
\text { 6. Praktik dilakukan } \\
\text { oleh siswa secara } \\
\text { individu. } \\
\text { 7. Siswa melaksanakan } \\
\text { praktik sesuai } \\
\text { dengan panduan job } \\
\text { sheet atau sudah } \\
\text { disesuaikan dengan } \\
\text { kompetensi dasar. } \\
\text { 8. Pembelajaran praktik } \\
\text { lebih banyak } \\
\text { waktunya daripada } \\
\text { teori. } \\
\text { 9. Proporsi praktik } 60 \% \\
\text { dan teori 40\% } \\
\text { andian }\end{array}$ & $\begin{array}{l}\text { 2. Menekankan } \\
\text { pembelajaran aktif, } \\
\text { kreatif dan } \\
\text { menyenangkan } \\
\text { (PAKEM), student } \\
\text { centered, reflective } \\
\text { learning, active learning, } \\
\text { enjoyble and joyful } \\
\text { learning, cooperative } \\
\text { learning, quantum } \\
\text { learning, learning } \\
\text { revolution and } \\
\text { contextual learning. } \\
\text { 3. Lingkungan belajar yang } \\
\text { kondusif. } \\
\text { 4. Pengelolaan kelas yang } \\
\text { efektif. } \\
\text { 5. Penggunaan media dan } \\
\text { strategi pembelajaran. } \\
\text { 6. Pembelajaran teori daan } \\
\text { praktik dilaaksanakan } \\
\text { secara menyatuh. } \\
\text { 7. Praktik dilakukan oleh } \\
\text { siswa secara individu. } \\
\text { 8. Siswa melaksanakan } \\
\text { praktik sesuai dengan } \\
\text { panduan job sheet atau } \\
\text { sudah disesuaikan } \\
\text { dengan kompetensi } \\
\text { dasar. } \\
\text { 9. Pembelajaran praktik } \\
\text { lebih banyak waktunya } \\
\text { daripada teori. } \\
\text { Proporsi praktik } \\
\text { 60\% dan teori } 40 \% \\
\text { 10. }\end{array}$ & $\begin{array}{l}\text { of discovery. } \\
\text { 2. Menekankan pada } \\
\text { pembelajaran aktif, kreatif } \\
\text { dan menyenangkan } \\
\text { (PAKEM). } \\
\text { 3. Lingkungan belajar yang } \\
\text { kondusif. } \\
\text { 4. Media dan strategi } \\
\text { pembelajaran dan strategi } \\
\text { pembelajaran. } \\
\text { 5. Pengelolaan kelas. } \\
\text { 6. Pembelajaran teori daan } \\
\text { praktik dilaaksanakan } \\
\text { secara menyatuh. } \\
\text { 7. Praktik dilakukan oleh } \\
\text { siswa secara individu. } \\
\text { 8. Siswa melaksanakan } \\
\text { praktik sesuai dengan } \\
\text { panduan job sheet atau } \\
\text { sudah disesuaikan dengan } \\
\text { kompetensi dasar. } \\
\text { 9. Pembelajaran praktik } \\
\text { lebih banyak waktunya } \\
\text { daripada teori. } \\
\text { 10. Proporsi praktik } 60 \% \\
\text { dan teori } 40 \%\end{array}$ \\
\hline 3 & $\begin{array}{l}\text { Pendidik } \\
\text { dan } \\
\text { tenaga } \\
\text { kependidi } \\
\text { kan }\end{array}$ & $\begin{array}{l}\text { 1. Standar pendidik } \\
\text { dan tenaga } \\
\text { kependidikan. } \\
\text { 2. Kualifikasi dan } \\
\text { kompetensi } \\
\text { pendidik sudah } \\
\text { sesuai. } \\
\text { 3. Jumlah pendidik } \\
\text { dan tenaga }\end{array}$ & $\begin{array}{l}\text { 1. Menggunakan standar } \\
\text { pendidik dan tenaga } \\
\text { kependidikan. } \\
\text { 2. Kualifikasi pendidik } \\
\text { sudah sesuai. } \\
\text { 3. Kompetensi pendidik } \\
\text { dan tenaga kependidikan } \\
\text { sudah sesuai. } \\
\text { 4. Jumlah pendidik dan }\end{array}$ & $\begin{array}{l}\text { 1. Menggunakan standar } \\
\text { proses dalam PBM. } \\
\text { 2. Kualifikasi dan } \\
\text { kompetensi sudah sesuai. } \\
\text { 3. Jumlah pendidik dan } \\
\text { tenaga kependidikan } \\
\text { sudah memadai. } \\
\text { 4. Relevansi yang tinggi, } \\
\text { dalam arti kemampuan }\end{array}$ \\
\hline
\end{tabular}




\begin{tabular}{|c|c|c|c|c|}
\hline No & $\begin{array}{c}\text { Kompone } \\
\mathbf{n}\end{array}$ & SMKN 2 Yogyakarta & SMKN 2 Depok & SMKN 2 Wonosari \\
\hline & & $\begin{array}{l}\text { kependidikan sudah } \\
\text { memadai. } \\
\text { 4. Penyusunan silabus. } \\
\text { 5. Penyusunan RPP. } \\
\text { 6. Pengembangan } \\
\text { bahan ajar. } \\
\text { 7. Pengembangan alat } \\
\text { penilaian. } \\
\text { 8. Sudah melakukan } \\
\text { PBM yang efektif. } \\
\text { 9. Sudah efektif dalam } \\
\text { MGMP/KKM/KKG } \\
\text {. } \\
\text { 10. Relevansi yang } \\
\text { tinggi, dalam arti } \\
\text { kemampuan yang } \\
\text { dimiliki guru sesuai } \\
\text { dengan mata } \\
\text { pelajaran yang } \\
\text { diampu. } \\
\text { 11. Sertifikat profesi } \\
\text { sebagai guru. } \\
\text { 12. Kesanggupan kerja } \\
\text { yang tinggi. } \\
\text { 13. Menggunakan ICT } \\
\text { dalam mengajar. } \\
\text { 14. Mendorong } \\
\text { terjadinya dialog } \\
\text { dengan dan antar } \\
\text { siswa. } \\
\text { 15. Mendorong siswa } \\
\text { untuk berfikir, } \\
\text { melalui pertanyaan- } \\
\text { pertanyaan terbuka } \\
\text { dan mendorong } \\
\text { siswa untuk } \\
\text { bertanya sesama } \\
\text { teman. } \\
\text { 16. Memberikan waktu } \\
\text { berfikir yang cukup } \\
\text { bagi siswa dalam } \\
\text { menjawab } \\
\text { pertanyaan. }\end{array}$ & $\begin{array}{l}\text { tenaga kependidikan } \\
\text { sudah memadai. } \\
\text { 5. Memiliki tingkat } \\
\text { relevansi yang tinggi, } \\
\text { dalam arti kemampuan } \\
\text { yang dimiliki guru sesuai } \\
\text { dengan mata pelajaran } \\
\text { yang diampu. } \\
\text { 6. Semua guru sudah } \\
\text { melakukan persiapan, } \\
\text { pelaksanaan dan evaluasi } \\
\text { pembelajaran sebelum } \\
\text { melakukan pelaksanaan } \\
\text { PBM di dalam kelas, } \\
\text { bengkel dan } \\
\text { laboratorium. } \\
\text { 7. Sebagian besar memiliki } \\
\text { sertifikat profesi sebagai } \\
\text { guru. } \\
\text { 8. Memiliki kesanggupan } \\
\text { kerja yang tinggi. } \\
\text { 9. Mampu menggunakan } \\
\text { ICT dalam mengajar. } \\
\text { 10. Guru sudah } \\
\text { menggunakan data } \\
\text { mentah sebagai sumber } \\
\text { utama pada fokus materi } \\
\text { pembelajaran. } \\
\text { 11. Penyusunan silabus. } \\
\text { 12. } \quad \text { Penyusunan RPP. } \\
\text { 13. Pengembangan } \\
\text { bahan ajar. } \\
\text { 14. Pengembangan alat } \\
\text { penilaian. } \\
\text { 15. Sudah melakukan } \\
\text { PBM yang efektif. } \\
\text { 16. Sudah efektif dalam } \\
\text { MGMP/KKM/KKG. }\end{array}$ & 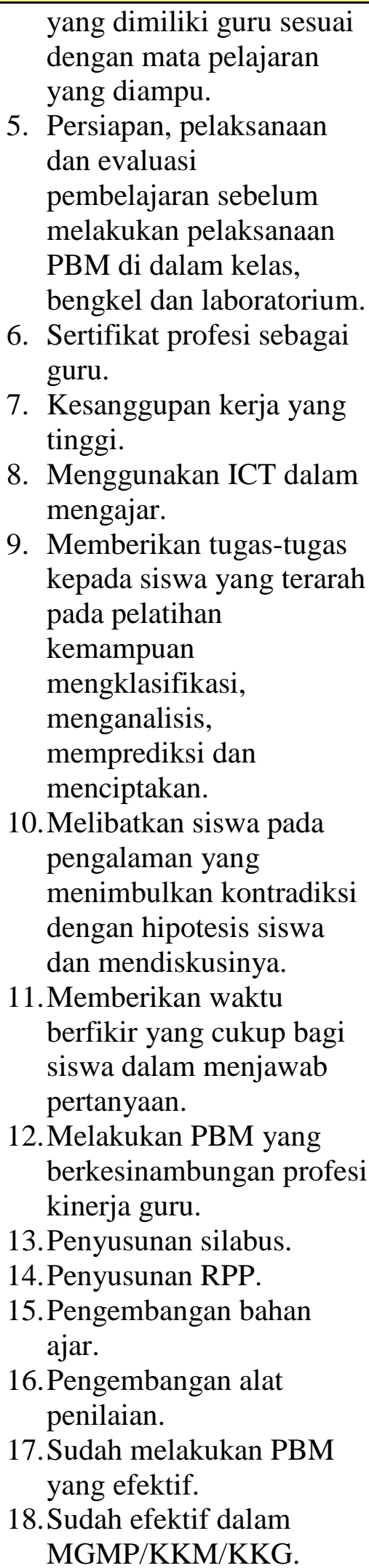 \\
\hline 4 & $\begin{array}{l}\text { Penilaian } \\
\text { pendidika }\end{array}$ & $\begin{array}{l}\text { 1. Menggunakan } \\
\text { standar penilaian }\end{array}$ & $\begin{array}{l}\text { Sudah menggunakan } \\
\text { standar penilaian KTSP. }\end{array}$ & $\begin{array}{l}\text { 1. Sudah menggunakan } \\
\text { standar penilaian KTSP. }\end{array}$ \\
\hline
\end{tabular}




\begin{tabular}{|c|c|c|c|c|}
\hline No & $\begin{array}{c}\text { Kompone } \\
\text { n }\end{array}$ & SMKN 2 Yogyakarta & SMKN 2 Depok & SMKN 2 Wonosari \\
\hline & $\mathrm{n}$ & \begin{tabular}{|l} 
2. \\
MTSP. \\
penilaian PAP. \\
3. Menggunakan \\
kriteria ketuntasan \\
minimal. \\
4. Pekerjaan siswa \\
dikembalikan \\
setelah di koreksi \\
oleh guru yang \\
mengampu mata \\
pelajaran tersebut. \\
5. Transparan dan \\
objektif. \\
6. Penilaian praktik \\
dilaksanakan secara \\
objektib dan \\
individu. \\
7. Pelaksanaan praktik \\
dilakukan secara \\
individu dan \\
penilaian pun sudah \\
dilakukan oleh guru \\
yang bersangkutan \\
8. Penilaian praktik \\
dilaksanakan oleh \\
guru sesuai dengan \\
tingkat kompetensi \\
dasar. \\
9. Penilaian praktik \\
juga menggunakan \\
sistem GO dan NO \\
GO. \\
10. Hasil penilaian \\
praktik selalu \\
diumumkan untuk \\
menghakhiri \\
kompetensi dasar
\end{tabular} & \begin{tabular}{|l} 
2. \\
Penggunakan penilaian \\
PAP. \\
Menggunakan kriteria \\
ketuntasan minimal. \\
4. Memberikan informasi \\
akurat tentang prestasi \\
belajar siswa dalam \\
berbagai mata pelajaran \\
dan perkembangan \\
kemajuan sosial siswa. \\
5. Ttransparan dan objektif \\
dalam memberikan nilai. \\
6. Penilaian praktik \\
dilaksanakan secara \\
objektib dan individu. \\
7. Pelaksanaan praktik \\
dilakukan secara \\
individu dan penilaian \\
pun sudah dilakukan \\
oleh guru yang \\
bersangkutan \\
8. Penilaian praktik \\
dilaksanakan oleh guru \\
sesuai dengan tingkat \\
kompetensi dasar. \\
9. Penilaian praktik juga \\
menggunakan sistem \\
GO dan NO GO. \\
10. Hasil penilaian praktik \\
selalu diumumkan untuk \\
menghakhiri kompetensi \\
dasar
\end{tabular} & $\begin{array}{l}\text { 2. Menggunakan kriteria } \\
\text { ketuntasan minimal. } \\
\text { 3. Hasil pekerjaan siswa } \\
\text { dikembalikan setelah di } \\
\text { koreksi oleh guru yang } \\
\text { mengampu mata pelajaran } \\
\text { tersebut. } \\
\text { 4. Transparan dan objektif } \\
\text { dalam penilaian. } \\
\text { 5. Penilaian praktik } \\
\text { dilaksanakan secara } \\
\text { objektib dan individu. } \\
\text { 6. Pelaksanaan praktik } \\
\text { dilakukan secara individu } \\
\text { dan penilaian pun sudah } \\
\text { dilakukan oleh guru yang } \\
\text { bersangkutan } \\
\text { 7. Penilaian praktik } \\
\text { dilaksanakan oleh guru } \\
\text { sesuai dengan tingkat } \\
\text { kompetensi dasar. } \\
\text { 8. Penilaian praktik juga } \\
\text { menggunakan sistem GO } \\
\text { dan NO GO. } \\
\text { 9. Hasil penilaian praktik } \\
\text { selalu diumumkan untuk } \\
\text { menghakhiri kompetensi } \\
\text { dasar }\end{array}$ \\
\hline 5 & $\begin{array}{l}\text { Kultur } \\
\text { sekolah }\end{array}$ & $\begin{array}{l}\text { Kultur yang kondusif } \\
\text { bagi peningkatan } \\
\text { efektivitas sekolah } \\
\text { pada umumnya dan } \\
\text { efektivitas } \\
\text { pembelajaran pada } \\
\text { khususnya, yang } \\
\text { dibuktikan oleh }\end{array}$ & \begin{tabular}{|l|} 
Kultur yang kondusif bagi \\
peningkatan efektivitas \\
sekolah pada umumnya dan \\
efektivitas pembelajaran \\
pada khususnya, yang \\
dibuktikan oleh berpusat \\
pada pengembangan peserta \\
didik, lingkungan belajar
\end{tabular} & $\begin{array}{l}\text { Menumbuhkan dan } \\
\text { mengembangkan kultur yang } \\
\text { kondusif bagi peningkatan } \\
\text { efektivitas sekolah pada } \\
\text { umumnya dan efektivitas } \\
\text { pembelajaran pada } \\
\text { khususnya, yang dibuktikan } \\
\text { oleh berpusat pada }\end{array}$ \\
\hline
\end{tabular}




\begin{tabular}{|c|c|c|c|c|}
\hline No & $\begin{array}{c}\text { Kompone } \\
\text { n }\end{array}$ & SMKN 2 Yogyakarta & SMKN 2 Depok & SMKN 2 Wonosari \\
\hline & & $\begin{array}{l}\text { berpusat pada } \\
\text { pengembangan peserta } \\
\text { didik, lingkungan } \\
\text { belajar yang kondusif, } \\
\text { penekanan pada } \\
\text { pembelajaran, } \\
\text { profesionalisme, } \\
\text { harapan tinggi, } \\
\text { keunggulan, respek } \\
\text { terhadap setiap } \\
\text { individu warga } \\
\text { sekolah, keadilan, } \\
\text { kepastian, kultur } \\
\text { korporasi atau } \\
\text { kebiasaan bekerja } \\
\text { secara } \\
\text { kolaboratif/kolektif, } \\
\text { kebiasaan menjadi } \\
\text { masyarakatbelajar, } \\
\text { wawasan masa depan } \\
\text { (visi) yang sama, } \\
\text { perencanaan bersama, } \\
\text { kolegialitas, tenaga } \\
\text { kependidikan sebagai } \\
\text { pembelajaran, } \\
\text { masyarakat belajar, } \\
\text { pemberdayaan bersama } \\
\text { dan kepemimpinan } \\
\text { transformatif dan } \\
\text { partisipatif. } \\
\text { Kultur DUDI sudah } \\
\text { dilaksanakan dengan } \\
\text { baik, dimana setiap } \\
\text { praktik selalu } \\
\text { menggunakan pakaian } \\
\text { praktik untuk } \\
\text { memasuki bengkel dan } \\
\text { laboratorium. } \\
\text { Kultur DUDI sudah }\end{array}$ & $\begin{array}{l}\text { yang kondusif, penekanan } \\
\text { pada pembelajaran, } \\
\text { profesionalisme, harapan } \\
\text { tinggi, keunggulan, respek } \\
\text { terhadap setiap individu } \\
\text { warga sekolah, keadilan, } \\
\text { kepastian, kultur korporasi } \\
\text { atau kebiasaan bekerja } \\
\text { secara kolaboratif/kolektif, } \\
\text { kebiasaan menjadi } \\
\text { masyarakatbelajar, } \\
\text { wawasan masa depan (visi) } \\
\text { yang sama, perencanaan } \\
\text { bersama, kolegialitas, } \\
\text { tenaga kependidikan } \\
\text { sebagai pembelajaran, } \\
\text { masyarakat belajar, } \\
\text { pemberdayaan bersama dan } \\
\text { kepemimpinan } \\
\text { transformatif dan } \\
\text { partisipatif. } \\
\text { Kultur DUDI sudah } \\
\text { dilaksanakan dengan baik, } \\
\text { dimana setiap praktik selalu } \\
\text { menggunakan pakaian } \\
\text { praktik untuk memasuki } \\
\text { bengkel dan laboratorium. } \\
\text { Kultur DUDI sudah terlihat } \\
\text { di SMK dimana peralatan } \\
\text { mesin-mesin sudah nampak } \\
\text { dan digunakan praktik oleh } \\
\text { siswa secara individu. }\end{array}$ & $\begin{array}{l}\text { pengembangan peserta didik, } \\
\text { kerjasama, kepala sekolah, } \\
\text { lingkungan belajar yang } \\
\text { kondusif, penekanan pada } \\
\text { pembelajaran, } \\
\text { profesionalisme, harapan } \\
\text { tinggi, keunggulan, respek } \\
\text { terhadap setiap individu } \\
\text { warga sekolah, keadilan, } \\
\text { kepastian, kultur korporasi } \\
\text { atau kebiasaan bekerja secara } \\
\text { kolaboratif/kolektif, } \\
\text { kebiasaan menjadi } \\
\text { masyarakatbelajar, wawasan } \\
\text { masa depan (visi) yang sama, } \\
\text { perencanaan bersama, } \\
\text { kolegialitas, tenaga } \\
\text { kependidikan sebagai } \\
\text { pembelajaran, masyarakat } \\
\text { belajar, pemberdayaan } \\
\text { bersama dan kepemimpinan } \\
\text { transformatif dan partisipatif. } \\
\text { Kultur DUDI sudah } \\
\text { dilaksanakan dengan baik, } \\
\text { dimana setiap praktik selalu } \\
\text { menggunakan pakaian } \\
\text { praktik untuk memasuki } \\
\text { bengkel dan laboratorium. } \\
\text { Kultur DUDI sudah terlihat } \\
\text { di SMK dimana peralatan } \\
\text { mesin-mesin sudah nampak } \\
\text { dan digunakan praktik oleh } \\
\text { siswa secara individu. }\end{array}$ \\
\hline
\end{tabular}




\begin{tabular}{|l|l|l|l|l|}
\hline No & $\begin{array}{c}\text { Kompone } \\
\mathbf{n}\end{array}$ & SMKN 2 Yogyakarta & SMKN 2 Depok & SMKN 2 Wonosari \\
\hline & $\begin{array}{l}\text { terlihat di SMK dimana } \\
\text { peralatan mesin-mesin } \\
\text { sudah nampak dan } \\
\text { digunakan praktik oleh } \\
\text { siswa secara individu. }\end{array}$ & & \\
\hline
\end{tabular}




\section{Simpulan Dan Saran}

\section{A. Simpulan}

Berdasarkan hasil analisis data dari penelitian ini, maka dapat ditarik simpulan sebagai berikut: (1) Kurikulum yang digunakan dari ketiga SMKN di Yogyakarta sudah mengacu pada kurikulum KTSP dimana masingmasing sekolah sudah mengembangkan kurikulum sesuai dengan potensi daerahnya masing-masing. Jadi karakteristik kurikulum yang efektif dari ketiga SMKN di Yogyakarta sudah menggunakan, membuat dan melaksanakan standar isi, silabus, RPP, bahan ajar, media pembelajaran, metode atau strategis pembelajaran dan pengelolaan kelas. Pihak SMK pun sudah mengundang pihak DUDI untuk bersama-sama memberikan masukan terhadap kurikulum yang digunakan di SMK. Pengembangan kurikulum ini dimaksudkan agar adanya sikron antara kurikulum di SMK dengan DUDI atau juga disebut dengan link and match antara dunia SMK dengan DUDI. Jadi kurikulum yang digunakan ketiga SMKN di Yogyakarta sudah efektif dalam pembuatan dan pelaksanaan yang diberlakukan oleh pihak SMK dan DUDI. (2) Pelaksanaan PBM untuk teori dan praktik ketiga SMKN di DIY sudah di katakan efektif karena sudah membuat dan melaksanakan Satuan Acara Pelajaran (SAP) lengkap dengan elemen-elemennya (tujuan, alat evaluasi, bahan ajar, metode pembelajaran, media pendidikan/alat peraga, waktu dan sebagainya). Sekolah memiliki bukti bahwa guru menggunakan berbagai macam variasi strategi dalam pembelajaran, pendekatan dan metode pembelajaran yang mampu memberdayakan, meningkatkan efektivitas pembelajaran di dalam kelas, bengkel maupun laboratorium dan pengelolaan kelas, bengkel maupun laboratorium sudah baik. Sekolah memiliki bukti tingkat efektivitas perilaku mengajar guru (kejelasan mengajar, keantusiasan mengajar dan sebagainya) dan perilaku belajar siswa (semangat, keseriusan, kerajinan dan sebagainya) di kelas, bengkel dan laboratorium. Jadi pelaksanaan PBM untuk teori dan praktik ketiga SMKN di Yogyakarta sudah berjalan dengan efektif sesuai dengan standar proses yang terdiri dari persiapan mengajar, pelaksanaan mengajar dan evaluasi hasil belajar yang di terapkan di SMK. Tetapi perlu di tambah buku-buku referensi yang terbaru pada program keahlian masing-masing untuk mewujudkan sebagai SMK yang efektif. (3) Pendidik dan tenaga kependidikan ketiga SMKN di DIY sudah memenuhi kualifikasi S1 serta memiliki kompetensi kepribadian, kompetensi pedagogik, kompetensi profesional dan kompetensi sosial yang cukup memadai sebagai pendidik dan tenaga kependidikan. Apa lagi sebagian besar sudah berpendidikan S1 serta sudah bersertifikasi guru dengan adanya sertifikasi guru maka kualitas pendidikan di SMK dapat meningkat selain itu tenaga pendidik juga sudah profesional di bidangnya masingmasing. Ketiga SMKN di Yogyakarta sudah bisa menggunakan ICT karena di sekolah masingmasing diadakan pelatihan khusus untuk pendidik dan tenaga kependidikan yang belum bisa ICT. Dengan adanya pelatihan ICT diharapkan para pendidik dan tenaga kependidikan bisa melaksanakan tugas pendidik dan tenaga kependidikan secara profesional dalam bidangnya masing-masing. (4) Penilaian pendidikan untuk teori dan praktik di tiga SMKN di sudah menggunakan sistem penilaian yang standar dimana UAS sudah mengacu pada penilaian KTSP begitu pula dengan ujian kompetensi dan UN. Kriteria Ketuntasan Minimal (KKM) sudah diberlakukan di tiga SMKN di DIY dengan menetapkan Penilaian Acuan Patokan (PAP) yaitu pelajaran normatif $\geq$ 7,60 , pelajaran adaptif $\geq 7,60$, pelajaran produktif 7,60 dan pelajaran muatan lokal 7,50. Penilaian yang dilakukan di tiga SMKN di Yogyakarta sudah transfaran dan objektif karena pekerjaan siswa dikembalikan sesudah dikoreksi oleh guru yang bersangkutan. Siswa yang belum mencapai nilai KKM diadakan remidi di sekolah sesuai dengan mata pelajaran yang diremidi oleh 
siswa yang bersangkutan. Jadi sistem pelaksanaan penilaian pendidikan yang diterapkan di tiga SMKN di Yogyakarta sudah efektif dilakukan oleh setiap tenaga pendidik. Penilaian teori dan praktik sudah mengacu kepada penilaian yang standar. (5) Kultur sekolah ketiga SMKN di Yogyakarta sudah mempunyai kultur DUDI yang efektif karena SMK maniaturnya adalah DUDI. Dari ketiga SMKN tersebut sudah merencanakan dan melaksanakan teori dan praktik. Temuan penelitian memperlihatkan bahwa lingkungan SMKN di Yogyakarta sudah terlihat bersih, tertib, indah, rindang, aman, sehat, bebas asap rokok dan narkoba, bebas kekerasan dan berbudaya akhlak mulia. Dilain sisi SMKN di Yogyakarta sudah memperlihatkan kultur lingkungan sekolah yang efektif dimana sudah melaksanakan praktik di dalam bengkel dengan menggunakan pakaian sehingga seolah-olah sudah bekerja di DUDI.

\section{B. Saran}

Berkenaan dengan hasil penelitian tentang studi komparasi SMKN yang efektif di DIY, maka berikut ini ada beberapa saran yang dapat dipakai sebagai bahan pertimbangan dan pelaksanaan dalam mengembangkan SMK yang efektif di Indonesia pada umumnya. (1) Memperhatikan penyusunan kurikulum KTSP dengan pengembangan kurikulum SMK untuk mensikronkan antara kompetensi dasar di sekolah dengan di DUDI. (2) Memperhatikan pelaksanaan PBM yang dilakukan di dalam kelas, bengkel dan laboratorium sehingga dalam menjalankan tugas serta perbaikan secara terus menerus dan keterlibatan semua warga sekolah dalam pelaksanaan PBM yang pro-perubahan (kreatif, inovatif, eksperimentatif, inisiatif) serta berpikir sistem (berpikir holistik/tidak parsial, saling terkait dan terpadu) dan memberikan bantuan untuk anggaran pembelian buku-buku referensi yang terbaru pada setiap program keahlian di SMK dalam rangka mewujudkan sekolah efektif. (3) Memperhatikan pendidik dan tenaga kependidikan untuk kualifikasi dan kompetensi kepribadian, kompetensi pedagogik, kompetensi profesional dan kompetensi sosial. Selain itu, juga memperhatikan peningkatan kompetensi dasar di bidangnya masing-masing melalui studi lanjut, pelatihan, penataran maupun kursus yang menunjang peningkatan kompetensi pendidik dan tenaga kependidikan serta memperhatikan peningkatan kesejahteraan, penghargaan dan perlindungan pendidik dan tenaga kependidikan. Pengkoordinasikan dan penyerasian pendidik dan tenaga kependidikan yang ada disekolah untuk mencapai tujuan bersama. (4) Memperhatikan penyelenggaraan, pengawasan dan pemeriksaan Ujian Nasional (UN) dan Ujian Sekolah (US) sesuai dengan ketentuan dari pusat sehingga penilaian pendidikan benar-benar objektif dilakukan. (5) Mengembangkan kultur DUDI di lingkungan SMK sehingga lulusan pendidikan kejuruan mengetahui secara nyata kondisi industri yang sebenarnya.

\section{Daftar Pustaka}

Denzin, N. K \& Lincoln, Y. S. (Ed). (2009). Handbook of qualitative research. California: Sage Publications, Inc.

Finch, C. R \& Crunkilton. J. R. (1979). Curiculum development in vocational and technical education: planning, content, and implementation. Boston, Massachusetts: Allyn and Bacon, Inc.

Miller, Melvin D. (1986). Principles and a philosophy for vocational education the National center for reseach for vocational education. Ohio: Colombus.

Miles, M. B \& Huberman, A. M. (1994). Qualitative data analysis: An expanded sourcebook. London: Sange Publication. 
Ormrod, J. E. (2003). Educational psychology, developing learners. $\left(4^{\text {rd }}\right.$ ed). Merrill: Pearson Education, Inc.

Perkins, D. C. (1998). The Carl D. Perkins vocational and technical education act, public law 105-332. USA: U. S Departmen of Education. Diambil dari situs: (http://www.ed.gov/offices/OVAE/CTE/per kins.html.03-08).

Scheerens, J. (1992). Effective schooling: Research, theory and practice. Original Dutch Edition (1st ed). London England: Dotesios Ltd.

Segiovani, T. (1995). The principalsip: A replective pratice perspective. School Improvement Planning in washington State. $\left(3^{\text {rd }}\right.$ ed). Allyn \& Bacon. Needham Heights. M. A. EDF Spring 2003. Washington Superintendance of Public Instruction. Diakses 29 Februari 2010 dari http://cc.msnscache.com.

Slamet, P. H. (2005). MBS, life skills, KBK, $C T L$, dan saling keterkaitannya. Handout kapita selekta desentralisasi pendidikan di Indonesia. Jakarta: Departemen pendidikan nasional.

Walter R., John. (1993). Machining fundamentals. Fundamentals basic to industry. South Holland: The GoodheartWillcox Company, Inc. (http://gerogers@teach.purdue.edu.042004).

Wenrich, C. R \& Wenrich, W. J. (1974). Leadership in Administration of Vocational and Technical Education. Ohiu: Charles. E. Merril

Publishingco 